\title{
Blood Groups in the Nepalese Native Chicken
}

\author{
Yoshio Yamamoto, Ikuo Okada, Yoshizane Maeda ${ }^{1}$, Kenji Tsunoda ${ }^{2}$, \\ Takao NAMIKAWA ${ }^{3}$, Takashi AMANo", Takayoshi ShotAke ${ }^{5}$, \\ Takao NisHidA ${ }^{6}$ and H.B. RAJUBHANDORE ${ }^{7}$ \\ Faculty of Applied Biological Science, Hiroshima University, \\ Higashihiroshima-shi 724 \\ ${ }^{1}$ Faculty of Agriculture, Kagoshima University, Kagoshima-shi 890 \\ ${ }^{2}$ Showa University, School of Medicine, Shinagawa-ku, Tokyo 142 \\ ${ }^{3}$ Faculty of Agriculture, Nagoya University, Chikusa-ku, Nagoya-shi 464 \\ ${ }^{4}$ Tokyo University of Agriculture, Setagaya-ku, Tokyo 156 \\ ${ }^{5}$ Primate Reasearch Institute, Kyoto University, Inuyama-shi 484 \\ ${ }^{6}$ Nihon University, School of Veterinary Medicine, Fujisawa-shi 252 \\ ${ }^{7}$ Department of Livestock Development and Animal Health, Ministry \\ of Agriculture, Nepal
}

(Received May 17, 1990)

\begin{abstract}
The frequencies of blood group alleles in Nepalese native chickens wore investigated. A total of 243 blood samples were collected from the native chickens of four different geographical locations in Nepal. The gene frequencies at four blood group ( $A, B, D$ and $E$ ) loci were examined. At the $A$ locus, the frequency of genes having the $F$ factor was considerably higher than those of other factors, while the $C^{\prime}$ factor was not found in Nepalese native chickens. The frequency of the $A^{F}$ allele showed an altitudinal difference : i.e. the frequency was higher in high altitude areas than in low altitude areas. At the $B$ locus, the frequency of $B^{L}$ was higher in the lowland than other areas. The $B^{D}$ allele was found with the lowest frequency only in the Pokhara area. The $B^{A}, B^{E}$ and $B^{M}$ alelles were not found in Pokhara and lowland areas. The coefficient of gene differentiation $\left(G_{S T}\right)$ and the average heterozygosity $(\bar{H})$ per individual were estimated to evaluate genetic differentiation in Nepalese native chickens. The estimate of $G_{S T}$ was a comparatively low value, 0.1285 .
\end{abstract}

Anim. Sci. Technol. (Jpn.) $62(1): 1-6,1991$

key words : Nepal, blood groups, external character, native chicken

About nine million chickens are raised for meat and egg production in Nepal ${ }^{1}$. Although most of the chickens in Nepal are native chickens, the number of pure native chickens seems to be decreasing gradually. The Nepalese government is trying to improve productivity by introducing modern breeds such as the New Hampshire, Rhode Island Red, White Leghorn, White Cornish, and Barred Plymouth Rock. Therefore, it is an urgent problem to estimate the genetic background of Nepalese native chickens as a genetic resource.

The study of the frequencies of four blood loci of native chickens is part of a field survey done on Nepalese domestic animals.

\section{Materials and Methods}

\section{Areas surveyed}

Blood samples were collected from the native chickens in four different geographic locations. The number and locality of the collected blood samples are shown in Fig. 1. The highland is 


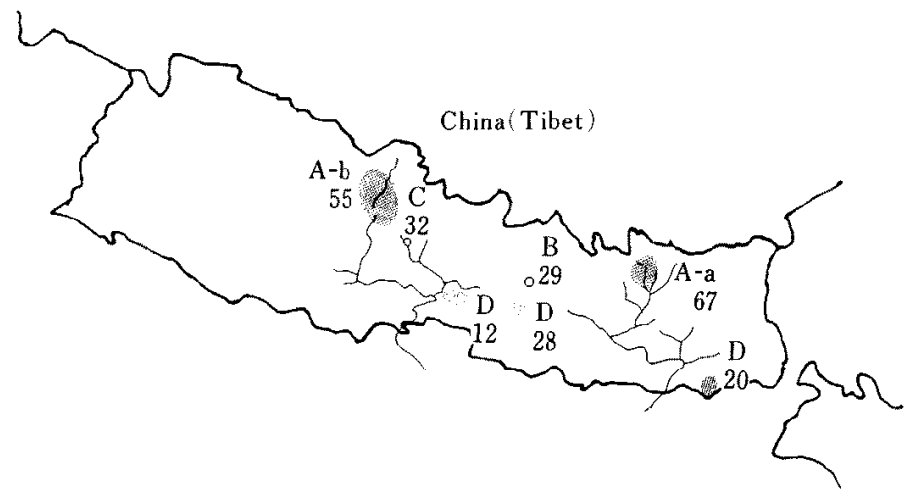

Fig. 1. Surveyed areas and number of chickens examined A-a : High land (Solu), A-b : High land (Jomson road), B : Kathmandu, C : Pokhara, D : Low land.

formed by a region of hills lying at an altitude between $1500 \mathrm{~m}$ to $3000 \mathrm{~m}$, Kathmandu is a basin lying at an altitude of about $1500 \mathrm{~m}$, while Pokhara is located at an altitude of $500 \mathrm{~m}$. The lowland is formed by the southern flat land lying at an altitude of less than $500 \mathrm{~m}$.

\section{Blood collection and blood typing}

Heparinized blood samples were collected from a wing vein and red blood cells were washed with a physiological saline by centrifugation (1500 rpm, for 5 minutes) three times. Four blood group systems of $A, B, D$, and $E$ were tested by hemagglutination. The number of reagents used for blood typing were four for $A$, ten for $B$, and two each for $D$ and $E$. systems. Blood typing was carried out at the Laboratory of Teaching Hospital, Tribhuvan University, Kathmandu.

The nomenclature of blood group alleles used in this study was given by MATSUmoto and $\mathrm{OKADA}^{8)}$ and is not necessarily the same as those of BRILES ${ }^{1,2}$.

Estimation of gene frequencies and genetic variability

The frequencies of the blood group alleles were estimated by the method described by ITo and KANEMAKI ${ }^{5}$.
Genetic variability within population was determined by measuring the average heterozygosity per individual, $\bar{H}$. The heterozygosity was calculated by the following formula ${ }^{10)}$ :

$$
\bar{H}=\overline{2 n\left(1-\sum x_{i}^{2}\right) /(2 n-1)}
$$

where $x_{i}$ is the frequency of the $i$ th allele at a locus, $n$ is the sample number and the bar is the overall average of the loci, including monomorphic loci.

The relative magnitude of genetic differentiation among local populations of the Nepalese native chickens was estimated using the coefficient of gene differentiation, $G_{S T}{ }^{9}$. . The coefficient was calculated by the following formula :

$$
G_{S T}=D_{S T} / H_{T}
$$

where $H_{T}$ is the average heterozygosity of the native chickens, calculated from the average gene frequencies of local populations, and $D_{S T}$ is the difference between the $H_{T}$ and $H_{S}$, the mean of average heterozygosity of local populations.

\section{Results and Discussions}

Table 1 shows the gene frequencies of the blood group $A$ locus in the Nepalese native chickens. The frequency of genes having the $F$ factor was considerably higher than those of 
Blood Groups of Chicken in Nepal

Table 1. Gene frequencies at the blood group 4 locus in the Nepalese native chickens

\begin{tabular}{|c|c|c|c|c|c|c|c|c|}
\hline \multirow[t]{2}{*}{ Locality } & \multirow{2}{*}{$\begin{array}{l}\text { No. of } \\
\text { birds }\end{array}$} & \multicolumn{6}{|c|}{ Gene frequency } & \multirow[b]{2}{*}{$a$} \\
\hline & & $A^{F}$ & $A^{R}$ & $A^{i}$ & $A^{F R}$ & $A^{F 2}$ & $A^{R Z}$ & \\
\hline High land & 122 & .4846 & .0840 & .0288 & .0164 & .0178 & 0 & .3683 \\
\hline Solu area & 67 & .4994 & .0798 & 0 & .0250 & .0230 & 0 & .3728 \\
\hline Jomson road area & 55 & .4425 & .0590 & .0603 & .0355 & .0170 & 0 & .3857 \\
\hline Kathmandu & 29 & .2348 & .1698 & .0526 & .0299 & 0 & 0 & .5100 \\
\hline Pokhara & 32 & .3293 & .0668 & 0 & 0 & 0 & 0 & .6036 \\
\hline Low land & 60 & .1183 & .2270 & .0262 & .1315 & 0 & .0346 & .4624 \\
\hline Total & 243 & .3216 & .1123 & .0255 & .0534 & .0161 & .0091 & .4620 \\
\hline
\end{tabular}

Table 2. Gene frequencies at the blood group $B$ locus in the Nepalese native chickens

\begin{tabular}{lcccccccccc}
\hline Locality & $\begin{array}{c}\text { No. of } \\
\text { birds }\end{array}$ & \multicolumn{7}{c}{ Gene frequency } \\
\cline { 5 - 11 } & & $B^{A X}$ & $B^{B X 1}$ & $B^{c}$ & $B^{D}$ & $B^{E}$ & $B^{G}$ & $B^{G X}$ \\
\hline High land & 122 & .0243 & .0162 & .0160 & 0 & .0114 & .0524 & .0288 \\
$\quad$ Solu area & 67 & .0411 & .0350 & 0 & 0 & 0 & 0 & .0192 \\
$\quad$ Jomson road area & 55 & 0 & 0 & .0186 & 0 & .0049 & .1202 & .0218 \\
Kathmandu & 29 & .0210 & .0175 & 0 & 0 & 0 & 0 & .0578 \\
Pokhara & 32 & 0 & .0206 & .1364 & .0230 & 0 & 0 & .0414 \\
Low land & 60 & 0 & 0 & 0 & 0 & 0 & .0701 & .0249 \\
Total & 243 & .0049 & .0149 & .0367 & .0023 & .0051 & .0345 & .0480 \\
\hline
\end{tabular}

${ }^{1} X$ indicates that some similar phenogroups were pooled

Table 2. Continued

\begin{tabular}{lcccccccc}
\hline \hline \multirow{2}{*}{ Locality } & \multirow{2}{*}{$\begin{array}{c}\text { No. of } \\
\text { birds }\end{array}$} & \multicolumn{7}{c}{ Gene frequency } \\
\cline { 4 - 9 } & & $B^{L}$ & $B^{L X}$ & $B^{M}$ & $B^{M X}$ & $B^{L M X}$ & $b$ & Others \\
\hline High land & 122 & .2408 & .0318 & .0486 & .0528 & .1165 & .3632 & .0240 \\
$\quad$ Solu area & 67 & .1729 & .0449 & .0389 & .1001 & .1375 & .3992 & .0112 \\
$\quad$ Jomson road area & 55 & .2390 & .0388 & .0876 & 0 & .1328 & .3027 & .0336 \\
Kathmandu & 29 & .0937 & .0558 & .0265 & .0175 & .1477 & .5350 & .0275 \\
Pokhara & 32 & .0258 & 0 & 0 & .0989 & .1071 & .4430 & .1029 \\
Low land & 60 & .4792 & .3297 & 0 & .0448 & .0183 & 0 & .0593 \\
Total & 243 & .2105 & .0490 & .0412 & .0974 & .1009 & .3270 & .0274 \\
\hline
\end{tabular}

other factors, while the $C^{\prime}$ factor was not found. The frequency of $A^{F}$ allele was lower than that of Bangladesh, but higher than those of Sri Lanka and Indonesian native chickens ${ }^{11}$. The frequency of a allele was similar to that of Sri Lanka ${ }^{11 \text {, }}$, but higher than that of Bangladesh native chickens. A difference in frequency was found in that the frequency of
$A^{F}$ allele was higher in the high altitude areas. A similar finding was reported in the frequency of $\mathrm{Hb}-1^{\mathrm{A}}$ allele of Bangladesh native chicken populations ${ }^{11}$.

The gene frequencies at the blood group $B$ locus are shown in Table 2 . The frequencies of blood group alleles at the $B$ locus showed considerable variation among local popula- 
Yamamoto, Okada, Maeda, Tsunoda, Namikawa, Amano, Shotake, Nishida and Rajubhandore

Table 3. Gene frequencies at the blood group $D$ and $E$ loci in the Nepalese native chickens

\begin{tabular}{|c|c|c|c|c|c|c|c|c|c|}
\hline \multirow[t]{3}{*}{ Locality } & \multirow{3}{*}{$\begin{array}{l}\text { No, of } \\
\text { birds }\end{array}$} & \multicolumn{7}{|c|}{ Gene frequency } & \multirow{3}{*}{$e$} \\
\hline & & \multicolumn{4}{|c|}{$D$ locus } & \multicolumn{3}{|c|}{$E$ locus } & \\
\hline & & $D^{\circlearrowleft}$ & $D^{s}$ & $D^{Q s}$ & $d$ & $E^{W}$ & $E^{Y}$ & $E^{W Y}$ & \\
\hline High land & 122 & .4408 & .1697 & .0042 & .3853 & .4719 & .0085 & .0330 & .4866 \\
\hline Solu area & 67 & .4900 & .1557 & .0069 & .3474 & .4731 & .0149 & .0232 & .4889 \\
\hline Jomson road area & 55 & .3918 & .1743 & .0057 & .4282 & .4768 & 0 & .0370 & .4862 \\
\hline Kathmandu & 29 & .4172 & .1504 & 0 & .4321 & .1490 & 0 & 0 & .8510 \\
\hline Pokhara & 32 & .1302 & .0594 & 0 & .7830 & .1598 & .0870 & 0 & .7527 \\
\hline Low land & 60 & .5533 & .1275 & .0627 & .2565 & .6891 & .0708 & 0 & .2401 \\
\hline Total & 243 & .4058 & .1346 & .0241 & .4355 & .4179 & .0366 & .0095 & .5359 \\
\hline
\end{tabular}

Table 4. Genetic variations of the local populations in Nepal

\begin{tabular}{lcc}
\hline \hline Locality & $\begin{array}{c}\text { No. of } \\
\text { birds }\end{array}$ & $\bar{H} \pm \mathrm{S} . \mathrm{E}$ \\
\hline High land & 22 & $0.6461 \pm 0.1026$ \\
$\quad$ Solu area & 67 & $0.6481 \pm 0.1220$ \\
$\quad$ Jomson road area & 55 & $0.6300 \pm 0.1320$ \\
Kathmandu & 29 & $0.4801 \pm 0.1935$ \\
Pokhara & 32 & $0.6175 \pm 0.1735$ \\
Low land & 60 & $0.6104 \pm 0.1027$ \\
Total & 243 & $0.6623 \pm 0.1178$ \\
\hline
\end{tabular}

tions. A total of 43 alleles were found at the $B$ locus in the Napalese native chicken. The number of alleles within the local populations varied from 8 to 18 . The highest frequency of $b$ allele was found in the Nepalcse native chicken, higher than those in native chickens of other Asian countries ${ }^{11}$. The $B^{L}$ allele was the next highest and this was higher in the lowland than those in Kathmandu, Pokhara and the highland populations. The $B^{D}$ allele was found with a low frequency only in the Pokhara population. The $B^{A}, B^{E}$ and $B^{M}$ alleles were not found in Pokhara and the lowland populations. The allele having a $G$ factor was found to have a similar frequency to Sri Lanka and Indonesian native chickens ${ }^{11,121}$, but this frequency was lower than those found in Japanese native chicken populations ${ }^{13)}$.

Concerning the $D$ and $E$ loci, their gene frequencies are shown in Table 3. The $D^{Q}$ allele was found with a considerably higher frequency in the Nepalese native chickens, which was similar to those in the Sri Lanka and Indonesian native chicken populations ${ }^{11,12}$. The frequency of $D^{Q}$ allele in Pokhara was lower than those found in other populations in Nepal. At the $E$ locus, the frequency of $E^{W}$ allele was similar to those of native chickens in Japan and other Asian countries ${ }^{11,13)}$. Its frequency in Kathmandu and Pokhara was lower than those found in other populations in Nepal.

To evaluate genetic differentiation and genetic variability within local chicken populations, and the average heterozygosity per individual $(\bar{H})$ was estimated as shown in Table 4 . The $\bar{H}$ values of Nepalese native chickens were estimated as 0.48 to 0.65 . These estimates were considerably higher than those of Japanese native chickens ${ }^{14)}$. The $\bar{H}$ in the present study was estimated only from blood group data, while the estimate for Japanese native chickens included data from blood groups and protein polymorphisms. In general, protein polymorphisms include many monomorphic loci, so, their $\bar{H}$ values estimated from the data of protein polymorphisms will be small $3,4,7$. The coefficient of gene differentitation in the Nepalese native chickens was estimated as 0.1285 . When the $G_{s t}$ value was compared with those of other native chickens and improved breeds, it was higher than those in 
Japanese and Bangladesh native chickens ${ }^{11}$. This was lower than those from improved breeds, such as White Leghorn and Rhode Island $\operatorname{Red}^{14)}$. These results suggest that the degree of genetic differentiation among the Nepalese native chicken populations is not pronounced.

\section{References}

1) Briles, W.E., Current status of blood groups in domestic birds. Z. Tierz. Züchtungsbiol., 79 : 371-391. 1964.

2) Briles, W.E. and R.W. Briles, Identification of haplotypes of the chicken major histocompatibility complex $(B)$. Immunogenetics, $15: 449-459.1982$.

3) Hashiguchi, T., T. Nishida, Y. Hay ashi and S.S. MANSJOER, Blood protein variations of the native and the jungle fowls in Indonesia. Rep. Soc. Res. Native Livestock, 10:190-200. 1983.

4) Hashiguchi, T., S. Okamoto, T. Nishida, Y. Hayashi, H. Goto and H.W. Cyril, Blood protein variations of the Ceylon jungle fowl and native fowl in Sri Lanka. Rep. Soc. Res. Native Livestock, 11: 193207. 1986.

5) ITo, S. and M. KANEMAKI, A computeraided procedure for finding probable phenogroups from the phenotype distribution in the bovine B blood group system. Jpn. J. Zootech. Sci., 58: 591-603. 1987.

6) Joshi, R.M. and M.K. Khatiwada, Agri- cultural Handbook: Nepal, 154-157. Agri. Publication Series. Kathmandu. 1986.

7) MaEDa, Y., I. Okada, T. Hashiguchi and M.A. Hasnath, Blood protein polymorphisms of native fowl and red jungle fowl in Bangladesh. Rep. Soc. Res. Native Livestock, 12 : 233-250. 1988.

8) Matsumoto, K. and I. Orada, The blood group systems in the chicken. Jpn. J Genet., 36: 257-267. 1961.

9) Ner, M., Analysis of gene diversity in subdivided population. Proc, Nat. Acad. Sci., $70: 3321-3323.1973$.

10) Ner, M., Estimation of average heterozygosity and genetic distance from a small number of individuals. Genetics, $89: 583-$ 590. 1978

11) Okada, I., Y, Magda and M.M. Hasnath, Blood groups of indigenous chickens in Bangladesh. Rep. Soc. Res. Native Livestock, 12:227-232. 1988.

12) Okada, I., T. Nishida, T. Hashiguchi and S. ITo, Blood group variations in native fowls in indonesia. Rep. Soc. Res. Native Livestock, 10: 201-208. 1983.

13) OKADA, I., Y. YAMAMOTO, T. HASHIGUCHI and S. ITo, Phylogenetic studies on the Japanese native breeds of chickens. Jpn. Poult. Sci., 21 : 318-329. 1984.

14) Okada, I., Y. Yamamoto, A. Shinjo, S, Kimura and $\mathrm{H}$. Hiraoka, Studies of genetic differentiation within breeds of Japanese indigenous chickens, Jpn. Poult. Sci., 26 : 207-215, 1989. 
Yamamoto, Okada, Maeda, Tsunoda, Namikawa, Amano, Shotake, Nishida and Rajubhandore

$$
\text { ネパール在来鶏の血液型 }
$$

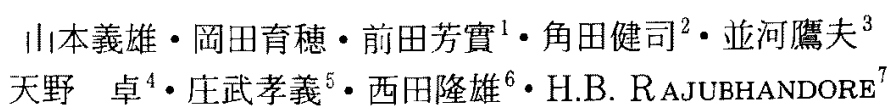

広島大学生物生産学部，東広島市 724

${ }^{1}$ 鹿児島人学農学部，鹿児島节 890

${ }^{2}$ 昭和大学医学部，東京都品川区 142

${ }^{3}$ 名古屋大学砧学部, 名古屋市千種区 464

${ }^{4}$ 東京農㹈大学, 東京都世田谷区 156

5 京都大学霊長類研究所, 犬山市 484

${ }^{6}$ 日本大学農獣医学部, 藤沢市 252

7 ネパール農務省, ネパール国

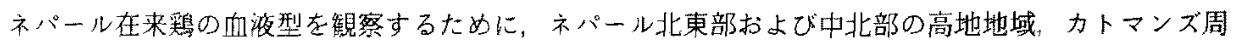
辺地域，ポ力ラ周辺地域，平野部の低地地域の 4 地域で合計 243 羽の在来熖より採血を行なった。血液 型の判定には 4 つのシステムを用い， $A$ システムは 4 種， $B$ システムは 11 種， $D$ と $E$ システムは各々 2 種の合計 19 種の抗血清を用いて频集反応を行なった，血液型の遣伝子頻度の分析を行ない，調查地 域間㧍よび他のアジア地域の在来鷅と比較検討した，得られた王な結果は以下の通りである。

1） $A$ 座值では， $F$ 因子を持つ遗伝子の頻度が他の因子を持つもの上り高いことが特徴的であり， $C^{\prime}$ 因子はネパール在来熖には認められなかった。 $A^{F}$ 遺云子の頻度には，北部の高地から南部の低地 への地理的な傾斜が見られた。

2） $B$ 座位では， $b$ 遗伝子の頻度が最す高く，他のアジア諸国の在来鷄と此べても高い頻度であっ た。一方， $B^{D}$ 遣伝子の頻度は最む低く，ポカラ周辺の在来䳕からのみ見い出された。 $B^{G}$ 遗伝子の頻 度はスリランカ, インドネシアおよびバングラデシュの在来舀の頻度と似ていたが日本在来鷄に比べて 低かった。

3） DおよびE座位については，これ迄調查されたアジアの在来晋と比較的似た傾向を示した。

4）ネパール在来鶏の地域集団間の迪伝的分化の程度を表す $G_{S T}$ は 0.125 之評価された。

日畜会報, $62(1) ： 1-6,1991$ 